\title{
Science To Support the Understanding of South Texas Surface- Water and Groundwater Resources in a Changing Landscape
}

\section{Introduction}

Against a backdrop of constant cycles of extreme hydrologic conditions ranging from oppressive droughts to life-threatening floods, the water-resource landscape of south Texas is undergoing constant change. Demands on water resources are increasing because of changes related to population growth, energy demands, agricultural practices, and other human-related activities. In south Texas, the Nueces, San Antonio, and Guadalupe River Basins cover approximately 50,000 square miles and include all or part of 45 counties (fig. 1). These stream systems transect the faulted and fractured carbonate rocks of the Edwards aquifer recharge zone and provide the largest sources of recharge to the aquifer. As the streams make their way to the Gulf of Mexico, they provide water for communities and ecosystems in south Texas and deliver water, sediment, and nutrients to the south Texas bays and estuaries.

The U.S. Geological Survey (USGS) works in cooperation with other local, State, and Federal agencies to provide timely access to water data, publications, and information to foster a better understanding of the water resources of south Texas. The USGS and our cooperators are involved in a wide variety of programs for collecting hydrologic data and scientific information in the changing landscape of south Texas to help our cooperators effectively address water-resource issues in this part of the State. This fact sheet provides an overview of our collaborative scientific endeavors in the basins of the Nueces, San Antonio, and Guadalupe Rivers and lower Rio Grande. An overview of USGS capabilities pertaining to water resource issues in Texas, including recently completed and ongoing studies in south Texas, is available at http://tx.usgs.gov/Capabilities/index.html.
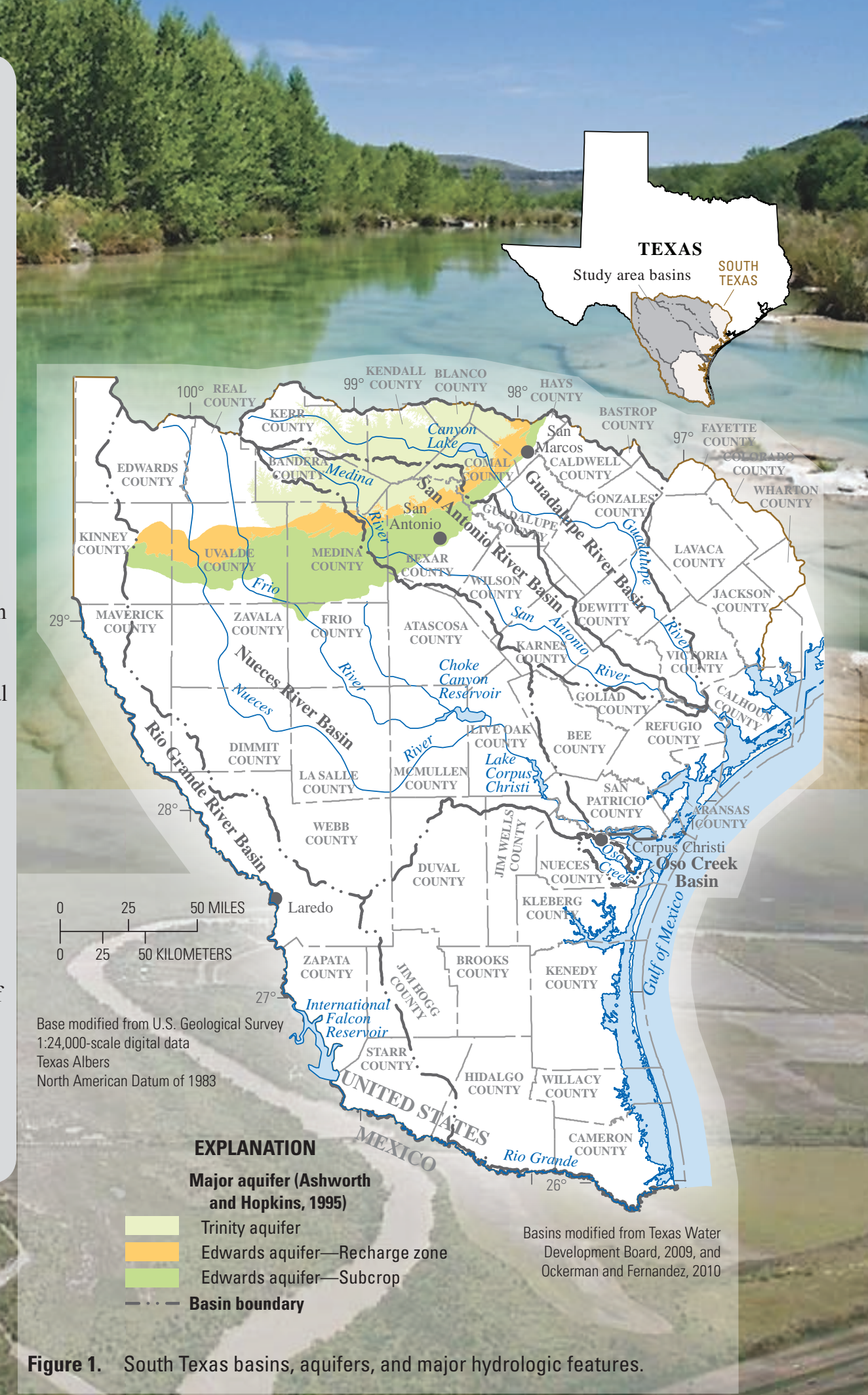

Figure 1. South Texas basins, aquifers, and major hydrologic features. 

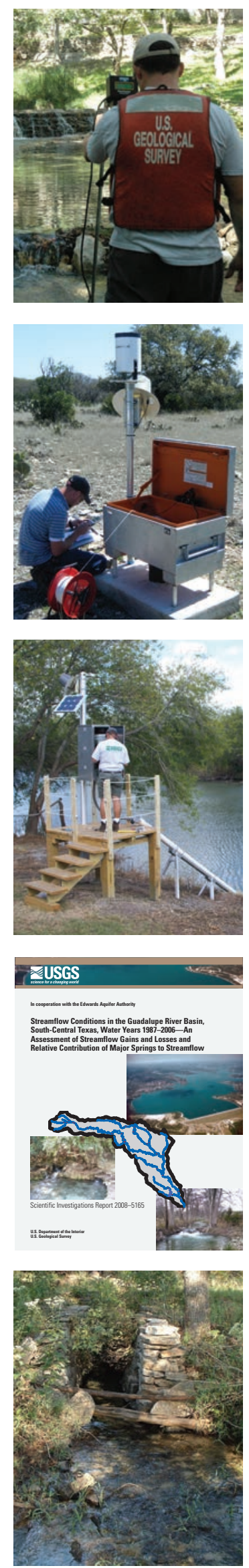

\section{Streamflow Data Available Online}

The USGS - in cooperation with numerous local, State, and Federal cooperators - operates a network of more than 100 streamflow-gaging stations in a 25-county area of south Texas. These stations typically record data at 15 -minute intervals and transmit the data to USGS offices every hour. Within minutes, the near real-time streamflow data are then posted to the Internet and available for viewing. In addition to these data, streamflow statistics, annual peak streamflows, and field measurement data from each station are also available on the Internet. Some of the uses of streamflow data include flood forecasting, water supply allocation, and hydraulic analyses.

http://waterdata.usgs.gov/tx/nwis/rt/

\section{Groundwater Data for Texas and the Nation}

The USGS groundwater database consists of more than 850,000 records of wells, springs, test holes, tunnels, drains, and excavations in the United States. Available site information includes well location information such as latitude and longitude, well depth, and the aquifer in which the well is completed. The USGS annually monitors groundwater levels in thousands of wells in the United States. Groundwater-level data are collected and stored either as discrete water-level measurements or as continuous time-series data from automated recorders. Data from some of the continuous record stations are relayed to USGS offices nationwide, providing public access to near real-time groundwater data.

http://waterdata.usgs.gov/nwis/gw

\section{Near Real-Time Water-Quality Monitoring}

The USGS operates a network of near real-time water-quality monitoring stations that provides in-stream and groundwater-quality measurement data, including temperature, specific conductance, $\mathrm{pH}$, dissolved oxygen, and turbidity. These data are needed for decision making regarding drinking water, water treatment, regulatory programs, recreation, healthy ecosystems, and public safety. Continuous, near real-time information on water quality is a vital asset that helps safeguard lives and property and ensures adequate water resources.

http://water.usgs.gov/owq/topics.html

\section{Assessment of Streamflow Gains and Losses in the Guadalupe River Basin}

The USGS - in cooperation with the Edwards Aquifer Authority - has evaluated data from USGS streamflow-gaging stations to determine streamflow gains and losses on reaches of the Guadalupe River and its major tributaries. The assessment also determined the relative contribution of major springs to streamflow in selected reaches of the Guadalupe River. During the selected short-term periods of August 2000 and August 2006 (periods of relatively low flow), springflow in defined sections of the Guadalupe River accounted for as much as 77 percent in 2000 and 78 percent in 2006 of total flow, compared with a springflow contribution of 18 percent during the long-term period of 1987-2006.

http://pubs.usgs.gov/sir/2008/5165/

\section{Trinity Aquifer Springs Survey}

The USGS - in cooperation with the Trinity Glen Rose Groundwater Conservation District, the San Antonio River Authority, and the Edwards Aquifer Authority-is documenting the location and the physicochemical properties of the springs issuing out of the Trinity aquifer in northern Bexar County. The karstic Trinity aquifer is a major source of water for central Texas. Springs issuing from the Trinity aquifer ultimately supply recharge either to deeper portions of the Trinity aquifer or to the Edwards aquifer that is exposed downgradient. 

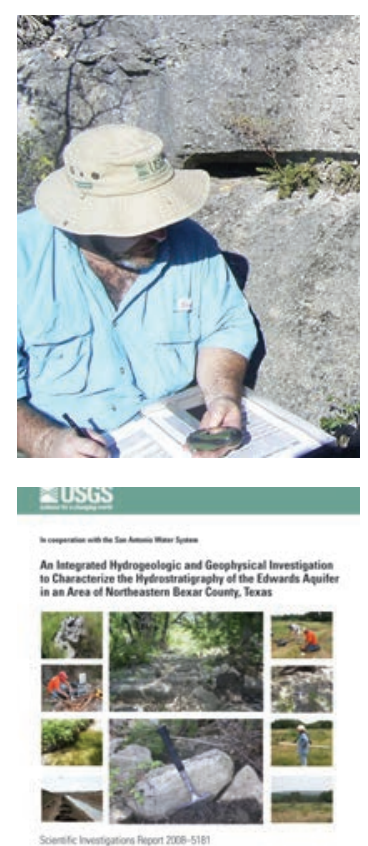

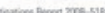

\#ت-

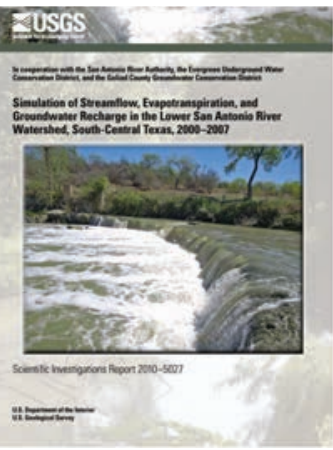

Zaves:
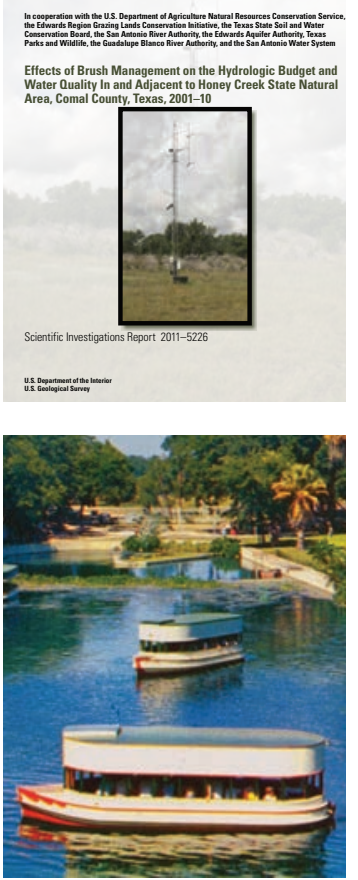

\section{Understanding the Complex Geology of the Trinity Aquifer}

As part of the National Cooperative Geologic Mapping Program, the USGS will use multidisciplinary science to help characterize the geologic framework of the Trinity aquifer of south Texas. The southern part of the Trinity aquifer forms the catchment area for the Edwards aquifer and might contribute to the water budget of the Edwards aquifer by subsurface flow across formation boundaries at considerable depths. The study area will be in south Texas north of San Antonio. In this area, the Trinity aquifer system is the primary source of water.

\section{Hydrogeologic and Geophysical Investigations of the Edwards Aquifer in Northeastern Bexar County}

The USGS - in cooperation with the San Antonio Water System - investigated hydrogeologic and geophysical properties to characterize the hydrostratigraphic zones and hydrogeologic features of the Edwards aquifer in a 16-square-kilometer area in northeastern Bexar County. Some areas on the Edwards aquifer recharge zone are undergoing rapid development, and the aquifer can be susceptible to contamination because of the presence of karst features, such as sinkholes and caves, that provide direct paths for urban runoff to move from the surface to the aquifer. The study identified areas where the Edwards aquifer might be susceptible because of urban development in northeastern Bexar County. http://pubs.usgs.gov/sir/2008/5181/

\section{Water Budget Model for the Lower San Antonio River Basin}

The USGS - in cooperation with the San Antonio River Authority, the Evergreen Underground Water Conservation District, and the Goliad County Groundwater Conservation District-configured, calibrated, and tested a watershed model for a study area consisting of about 2,150 square miles of the lower San Antonio River Basin in Bexar, Guadalupe, Wilson, Karnes, DeWitt, Goliad, Victoria, and Refugio Counties in south Texas. The model simulated streamflow, evapotranspiration, and groundwater recharge by using rainfall, meteorological data, and streamflow data. Future uses of the model could include simulating the effects of changes in land-cover and water use on water availability. http://pubs.usgs.gov/sir/2010/5027/

\section{A Paired Watershed Study on the Effects of Brush Management on the Hydrologic Budget}

The USGS - in cooperation with the Natural Resources Conservation Service and numerous others - is studying the effects of removing woody vegetation that might have encroached into historical savanna grassland ecosystems in Texas. In this study, a paired watershed approach was implemented to evaluate the effects of brush control on the hydrologic budget. In addition to daily rainfall and streamflow, evapotranspiration data were collected from 2001 to 2010 by using the Bowen ratio method. After measuring hydrologic conditions at both sites for the first 2 years of the study, the treatment watershed had selected brush removal of J uniperus ashei. The subsequent data were analyzed to detect changes in the hydrologic budget as a result of brush removal.

http://pubs.usgs.gov/sir/2011/5226/

\section{Sources of Recharge to San Marcos Springs}

The USGS - in cooperation with the San Antonio Water System - has collected groundwater, surface-water, and water-quality data to define and characterize the sources of recharge to springs in San Marcos, a main discharge point for the Edwards aquifer and the second largest spring complex in Texas. From December 2008 to December 2010, geochemical and hydrologic data were collected from groundwater, surface-water, and spring sites at or near San Marcos. Numerical and statistical methods, including geochemical modeling with PHREEQC, were used to evaluate the data to define and characterize local and regional sources of recharge to springs in San Marcos. 

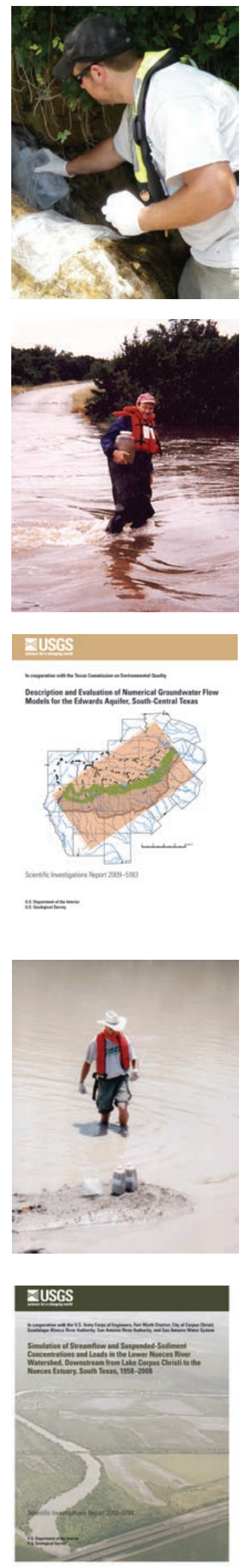

\section{Sources of Streamflow in the Upper Nueces River Basin}

The USGS - in cooperation with The Nature Conservancy and the U.S. Army Corps of EngineersFort Worth District - is measuring streamflow to help identify springs in the upper reaches of the Nueces River Basin, where streams are sustained by flow from springs located primarily in the uppermost reaches of the basin. Understanding of the location and quantities of springflow is important for preserving springs and the habitat they provide. The streamflow measurements are supplemented by analysis of water-quality samples, collected from groundwater wells, spring orifices, and streams, to help characterize groundwater contributions to streamflow.

\section{Characterization of Stormwater Runoff in the Edwards Aquifer Recharge Zone}

The USGS - in cooperation with the San Antonio Water System-is continuing to study the potential effect of runoff water quality on groundwater recharge for intermittent stream reaches within an active Edwards aquifer recharge zone. The primary goal of the study is to understand the influence of urban development on water quality within the Edwards aquifer, the major water source for the San Antonio area. The stream reaches being studied flow only during large rainfall events and for short periods of time. Therefore, sampling and data collection take place immediately following storm events to capture representative surface water that is likely to enter the Edwards aquifer. This information can be used by natural resource managers to protect groundwater quality in the Edwards aquifer.

\section{Edwards Aquifer Groundwater Modeling}

The USGS is active in the development and evaluation of numerical groundwater-flow models of the Edwards aquifer in south Texas. Regional-scale models have been developed by using MODFLOW, which emphasizes (1) conduit development and conduit flow (conduit-flow model) and (2) flow predominantly through a network of numerous small fractures and openings (diffuse-flow model). A local-scale model with 12 hydrogeologic units and 92 model layers was completed in 2010 to evaluate the movement of water and solutes to a selected public-supply well. The USGS also has evaluated various models with respect to accessibility and ease of use, range of conditions simulated, accuracy of simulations, agreement with dye-tracer tests, and limitations of the models. http://pubs.usgs.gov/sir/2009/5183/

\section{Sediment Monitoring in the Lower San Antonio and Guadalupe Rivers}

The USGS - in cooperation with the San Antonio River Authority and the Texas Water Development Board - initiated a study to characterize sediment dynamics in the lower San Antonio River. The study's first objective is to evaluate sediment transport in the lower San Antonio River and the Guadalupe River through collection of suspended-sediment, bedload, turbidity, and ancillary data. The second objective is to develop a sediment model for the lower San Antonio River to characterize sediment loading in these basins. This study will aid in understanding how urban development in the San Antonio area might be contributing excess sediment in the upper part of the basin. This study will also contribute to the understanding of coastal sediment delivery and how sediment loads are related to in-stream flows.

\section{Quantities and Sources of Suspended Sediment to Coastal Bays and Estuaries}

The USGS - in cooperation with the U.S. Army Corps of Engineers-Fort Worth District, City of Corpus Christi, Guadalupe-Blanco River Authority, San Antonio River Authority, and San Antonio Water System - developed, calibrated, and tested a Hydrological Simulation Program-FORTRAN watershed model. The model simulated the streamflow, suspended-sediment concentrations, and suspended-sediment loads during 1958-2008 in the Nueces River Basin, downstream from Lake Corpus Christi in south Texas. The model estimated contributions of suspended-sediment loads from various sources. Cropland in the basin was the largest source of suspended sediment, providing about 38 percent of the total suspended-sediment load to the estuary.

http://pubs.usgs.gov/sir/2010/5194/ 

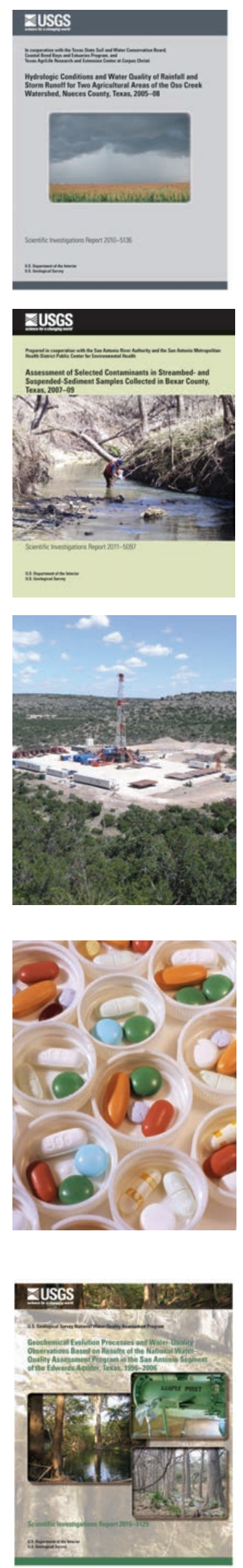

\section{Agricultural Runoff in the Texas Coastal Bend}

The USGS - in cooperation with Texas State Soil and Water Conservation Board, Coastal Bend Bays and Estuaries Program, and the Texas AgriLife Research and Extension Center at Corpus Christi-studied cropland runoff quality in the Oso Creek Basin in the Texas Coastal Bend. Land use surrounding Oso Creek is largely agricultural. Runoff samples collected during and after storm events were analyzed for nutrients, major inorganic ions, pesticides, and bacteria. Quantities of constituents in runoff were compared with quantities of fertilizers and pesticides applied to croplands. A better understanding of runoff patterns will contribute to future studies that focus on potential impacts to regional bays and estuaries.

http://pubs.usgs.gov/sir/2010/5136/

\section{Contaminants in Streambed and Suspended Sediments in the San Antonio Area}

Elevated concentrations of sediment-associated contaminants are typically found in urban areas, including San Antonio, the seventh most populous city in the United States. During 2007-9, the USGS-in cooperation with the San Antonio River Authority and the San Antonio Metropolitan Health District Public Center for Environmental Health — collected streambed sediment samples during base flow and suspendedsediment samples during stormwater runoff at 20 sites in the San Antonio River Basin. The samples were analyzed for major and trace elements and organic compounds including halogenated compounds and polycyclic aromatic hydrocarbons.

http://pubs.usgs.gov/sir/2011/5097/

\section{Assessing the San Antonio River Watershed for Possible Contaminants from Hydraulic Fracturing Fluid and Water Produced by Oil and Gas Activities}

The recent increase in hydraulic fracturing of gas and oil plays has contributed to a surge in oil and gas development, and in Texas there has been rapid development in the San Antonio River watershed. These activities have elicited concerns from the public about the potential risks to human and environmental health. The USGS - in cooperation with the San Antonio River Authority and the Guadalupe-Blanco River Authority — will evaluate a suite of water-quality constituents to help detect and monitor for possible hydraulic fracturing-derived contaminants in surface water and sediments in the lower San Antonio River Basin. This study will provide much needed baseline data for a broad spectrum of potential contaminants that might be associated with oil and gas production there.

\section{Pharmaceutical Compounds, Hormones, and Other Emerging Contaminants in the San Antonio River Basin, South Texas}

The USGS - in cooperation with the San Antonio River Authority - is assessing the occurrence and concentrations of approximately 100 different emerging contaminants at selected locations in the San Antonio River Basin. Emerging contaminants represent a new category of environmental pollutants that are derived from municipal, agricultural, and industrial wastewater sources. These chemicals include human and veterinary drugs, antibiotics, hormones, detergents, disinfectants, plasticizers, fire retardants, insecticides, and antioxidants. This study will provide information on the presence of detectable concentrations of those compounds in the San Antonio River Basin. These data can be used by resource professionals to assess vulnerability of public water supplies and ecosystems to pharmaceutical, hormone, and other emerging contaminants.

\section{National Water-Quality Assessment Program}

The USGS National Water-Quality Assessment (NAWQA) Program provides comprehensive information about water-quality conditions, evaluates changes in water quality over time on a national scale, and assesses how the environment and human activities affect water quality. Regional and national assessments are possible because of a consistent study design and uniform methods of data collection and analysis. Monitoring data are integrated with geographic information concerning hydrological characteristics, land use, and other landscape features in models to enhance our understanding of water-quality issues. Local, State, and national stakeholders use NAWQA Program information to design and implement strategies for managing, protecting, and monitoring water resources in many different hydrologic and land-use settings across the Nation. 

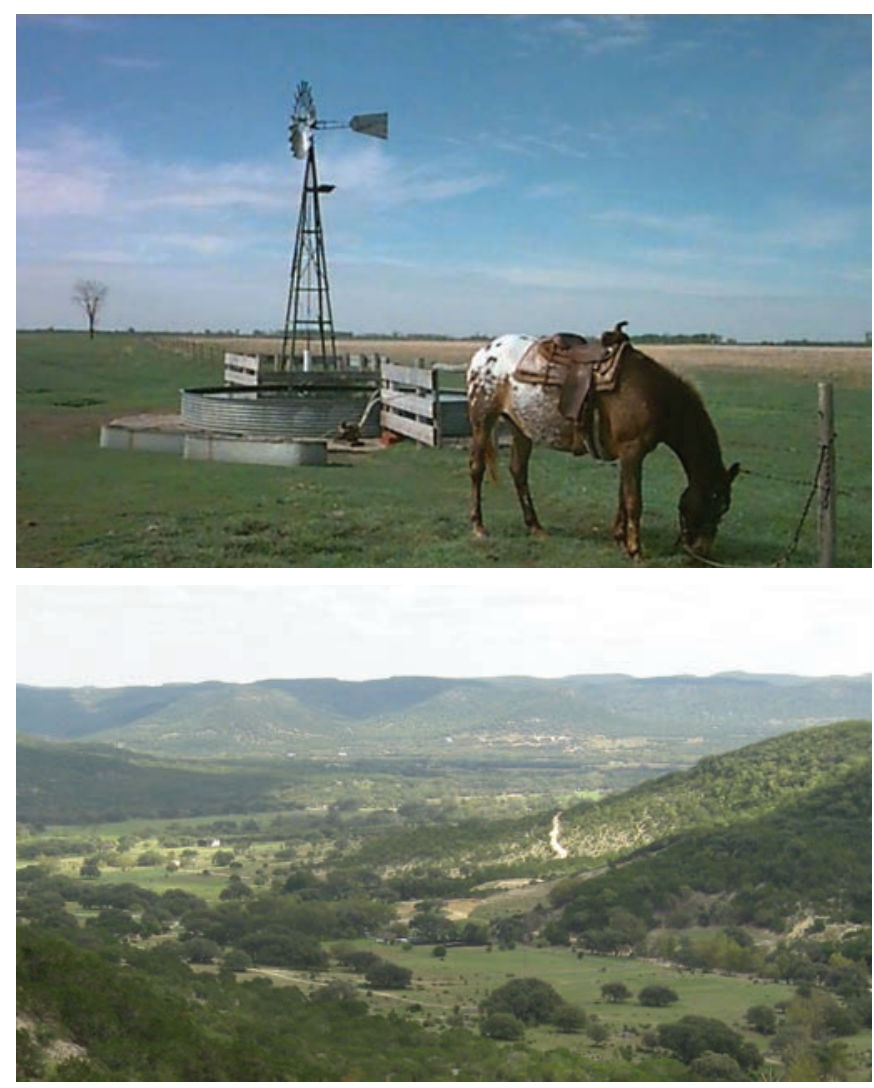

\section{References}

Ashworth, J., and Hopkins, J., 1995, Aquifers of Texas: Austin, Texas Water Development Board, Report 345.

Banta, J.R., and Slattery, R.N., 2011, Effects of brush management on the hydrologic budget and water quality in and adjacent to Honey Creek State Natural Area, Comal County, Texas, 2001-10: U.S. Geological Survey Scientific Investigations Report 2011-5226, 35 p., appendixes available online. (Also available at http://pubs.usgs.gov/sir/2011/5226/.)

Lindgren, R.J., Taylor, C.J., and Houston, N.A., 2009, Description and evaluation of numerical groundwater flow models for the Edwards aquifer, south-central Texas: U.S. Geological Survey Scientific Investigations Report 2009-5183, 25 p. (Also available at http://pubs.usgs.gov/sir/2009/5183/.)

Lizarraga, J.S., and Ockerman, D.J., 2010, Simulation of streamflow, evapotranspiration, and groundwater recharge in the lower San Antonio River watershed, south-central Texas, 2000-2007: U.S. Geological Survey Scientific Investigations Report 2010-5027, 41 p. (Also available at http://pubs.usgs.gov/sir/2010/5027/.)

Ockerman, D.J., and Fernandez, C.J., 2010, Hydrologic conditions and water quality of rainfall and storm runoff for two agricultural areas of the Oso Creek watershed, Nueces County, Texas, 2005-08: U.S. Geological Survey Scientific Investigations Report 2010-5136, 63 p. (Also available at http://pubs.usgs.gov/sir/2010/5136/.)

Ockerman, D.J., and Heitmuller, F.T., 2010, Simulation of streamflow and suspended-sediment concentrations and loads in the lower Nueces River watershed, downstream from Lake Corpus Christi to the Nueces Estuary, South Texas, 1958-2008: U.S. Geological Survey Scientific Investigations Report 2010-5194, 50 p. (Also available at http://pubs.usgs.gov/sir/2010/5194/.)

Ockerman, D.J., and Slattery, R.N., 2008, Streamflow conditions in the Guadalupe River Basin, south-central Texas, water years 1987-2006-An assessment of streamflow gains and losses and relative contribution of major springs to streamflow: U.S. Geological Survey Scientific Investigations Report 2008-5165, 22 p. (Also available at http://pubs.usgs.gov/ $\operatorname{sir} / 2008 / 5165 /$.

Shah, S.D., Smith, B.D., Clark, A.K., and Payne, J.D., 2008, An integrated hydrogeologic and geophysical investigation to characterize the hydrostratigraphy of the Edwards aquifer in an area of northeastern Bexar County, Texas: U.S. Geological Survey Scientific Investigations Report 2008-5181, 26 p. (Also available at http://pubs.usgs.gov/sir/2008/5181/.)
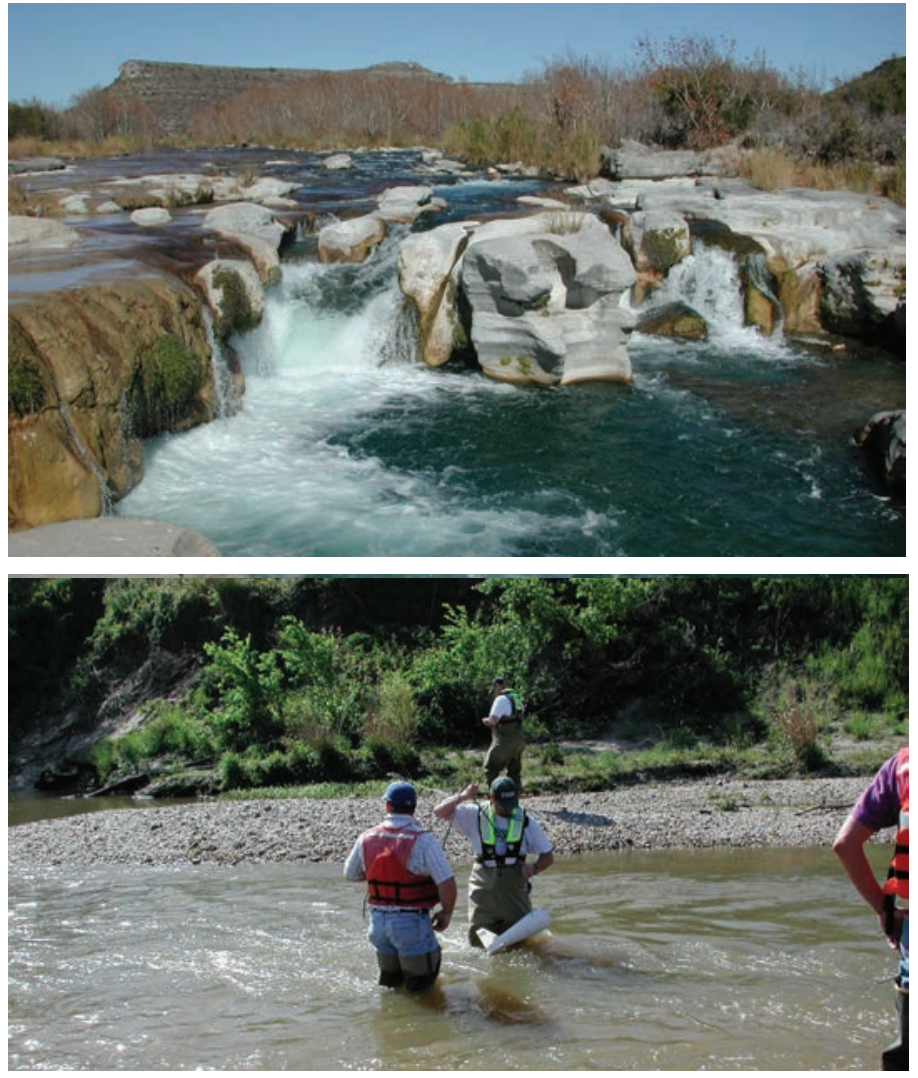

Texas Water Development Board, 2009, Major river basins in Texas: accessed February 27, 2012, at http://www.twdb.state.tx.us/mapping/maps/pdf/ mrb_8X11.pdf.

U.S. Geological Survey, 2011, Selected water-quality topics - Learn more about water quality: accessed February, 9, 2012, at http://water.usgs.gov/owq/ topics.html.

U.S. Geological Survey National Stream Quality Accounting Network, 2009, Monitoring the water quality of the Nation's large rivers, Rio Grande NASQAN Program: accessed February 9, 2012, at http://water.usgs.gov/ nasqan/docs/riogrndfact/riogrndfactsheet.html.

U.S. Geological Survey National Water Information System, 2011a, Web interface-USGS groundwater data for the Nation: accessed February 9, 2012, at http://waterdata.usgs.gov/nwis/gw.

U.S. Geological Survey National Water Information System, 2011b, Web interface-USGS real-time water data for Texas: accessed February 9, 2012, at http://waterdata.usgs.gov/tx/nwis/rt/.

U.S. Geological Survey National Water-Quality Assessment Program, 2012, Web page - National Water-Quality Assessment (NAWQA) Program: accessed February 9, 2012, at http://water.usgs.gov/nawqa/.

Wilson, J.T., 2011, Assessment of selected contaminants in streambed- and suspended-sediment samples collected in Bexar County, Texas, 2007-09: U.S. Geological Survey Scientific Investigations Report 2011-5097, 57 p. (Also available online at http://pubs.usgs.gov/sir/2011/5097/.)

\section{-Darwin J . O ckerman, Travis J. Garcia, and Stephen P. Opsahl}

This fact sheet is available online at http://pubs.usgs.gov.

\section{For additional information, contact}

Mark Null, Office Chief, jmnull@usgs.gov

U.S. Geological Survey Texas Water Science Center

South Texas Program Office

5563 De Zavala Rd., Suite 290

San Antonio, TX 78249

Phone: 210-691-9200 Fax: 210-691-9270

http://tx.usgs.gov/

Publishing support provided by

Lafayette Publishing Service Center 